\title{
Spatial structure of demersal fish assemblages in South and Southeast Asia and implications for fisheries management
}

\author{
L.R. Garces ${ }^{\text {a, }}$, I. Stobutzki ${ }^{\text {a }}$, M. Alias ${ }^{\text {b }}$, W. Campos ${ }^{\text {c }}$, N. Koongchai ${ }^{\text {d }}$,

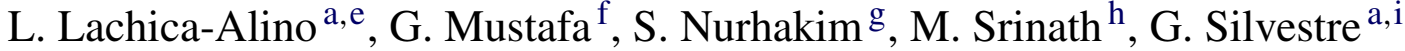 \\ ${ }^{a}$ WorldFish Center, PO Box 500 GPO, 10670 Penang, Malaysia \\ ${ }^{\mathrm{b}}$ Fisheries Research Institute, Department of Fisheries, Penang, Malaysia \\ ${ }^{\mathrm{c}}$ University of the Philippines in the Visayas, Miagao, Iloilo, Philippines \\ d Southern Marine Fisheries Research and Development Centre, Songkla 9000, Thailand \\ ${ }^{\mathrm{e}}$ University of the Philippines, Marine Science Institute, Diliman Quezon City, Philippines \\ ${ }^{\mathrm{f}}$ WorldFish Center, House 22B, Road 7, Block F, Banani Model Town, Dhaka 1213, Bangladesh \\ ${ }^{g}$ Research Center for Capture Fisheries, Agency for Marine and Fisheries Research, Jl. Pasir Putih I, Ancol Timor, Jakarta 14430, Indonesia \\ ${ }^{\mathrm{h}}$ Central Marine Fisheries Research Institute, Post Box No. 1603, Ernakulam, Cochin 682 014, India \\ ${ }^{\mathrm{i}}$ Tetra Tech EM Inc., 18th Floor, OMM-CITRA Bldg., San Miguel Avenue, Ortigas Center, Pasig City 1605, Philippines
}

\begin{abstract}
We provide a review of the assemblage structure of demersal fish resources in four South and Southeast Asian countries. Multivariate techniques (classification and ordination analysis) were used to analyze scientific trawl survey data from a collaborative project in the region. Analyses covered major coastal fishing areas in Bangladesh, Indonesia, Malaysia, and the Philippines. This represents the first such assessment of fish assemblages for the region using a standard analysis framework. Results indicate that spatial patterns of demersal assemblages are influenced by depth. However, other environmental factors such as salinity and substrate type also appear important. Critical fisheries management implications of the observed assemblage patterns are discussed, particularly in terms of the existing spatial management zones. Existing management zones are based on distance from shore and were found to be largely inconsistent with the assemblage patterns observed. If management is to be effective it must be structured to take into account the underlying pattern of the fish assemblages.
\end{abstract}

(C) 2006 Elsevier B.V. All rights reserved.

Keywords: Demersal fish assemblages; Experimental trawl surveys; Fisheries management; South and Southeast Asia

\section{Introduction}

The demersal fishery resources in tropical coastal areas such as those in Asia, consist of highly diverse, multi-species complexes (Longhurst and Pauly, 1987). These fisheries cannot be managed on the assumption they target single species. Therefore, managing the fisheries requires an understanding of the biological assemblage structure. An assemblage is operationally defined as the species available in the same place at the same time (Fauth et al., 1996). Ecological analysis of assemblage structure, since its early application based on vegetation ecology, has become increasingly important in the

\footnotetext{
* Corresponding author. Tel.: +60 4 6262173; fax: +60 46265530

E-mail address: 1.garces@ cgiar.org (L.R. Garces).
}

management of marine resources (McManus, 1997). Assemblage analyses can assist in defining "Assemblage Production Units" (Tyler et al., 1982), which can be used as the basis for assigning particular parts of the fishery to specific groups of fishers, gear types and harvest pressures (McManus, 1997). In addition, these analyses can provide a better understanding of the fundamental patterns of species abundances within harvested ecosystems, assist in identifying the effects of fishing and contribute to developing models to understand the structure of ecosystems (Suvavepun, 1991; McManus, 1997).

In Asia, there has been growing interest in the application of fish assemblage analysis to fisheries (e.g. Fager and Longhurst, 1968; Qui, 1988; McManus, 1986, 1989, 1996; Suvavepun, 1991; Bianchi, 1992, 1996; Chittima and Wannakiat, 1992; Federizon, 1992; Bianchi et al., 1996). In 
Table 1

Previous studies and inferred causes of assemblage structure in tropical Asia (modified from Silvestre et al., 2003)

\begin{tabular}{|c|c|c|c|}
\hline Region/survey area & Source & $\begin{array}{l}\text { Important } \\
\text { variables }\end{array}$ & Analysis method used \\
\hline Pakistan shelf & Bianchi (1992) & $\begin{array}{l}\text { Depth } \\
\text { temperature, } \\
\text { oxygen values }\end{array}$ & $\begin{array}{l}\text { TWINSPAN (Two-way } \\
\text { Indicator Species Analysis), } \\
\text { DCA (Detrended } \\
\text { Correspondence Analysis) }\end{array}$ \\
\hline Northwest coast of Sumatra (shelf region), Indonesia & Bianchi (1996) & Depth & TWINSPAN, DCA \\
\hline Java Sea (including part of southern South China Sea) & Bianchi et al. (1996) & $\begin{array}{l}\text { Depth, associated } \\
\text { habitat (estuaries) }\end{array}$ & TWINSPAN, DCA \\
\hline Eastern part of the Gulf of Thailand (off Chanthaburi) & Chittima and Wannakiat (1992) & Depth & Similarity index \\
\hline $\begin{array}{l}\text { Ragay Gulf, Burias Pass, Ticao Pass, north of Samar Sea, } \\
\text { Philippines }\end{array}$ & Federizon (1992) & $\begin{array}{l}\text { Depth, associated } \\
\text { habitats (e.g. } \\
\text { coralline areas) }\end{array}$ & $\begin{array}{l}\text { UPGMA (Unweighted } \\
\text { Pair-group Method using } \\
\text { Arithmetic Averages), } \\
\text { TWINSPAN, NMDS } \\
\text { (Nonmetric Multidimensional } \\
\text { Scaling), CA } \\
\text { (Correspondence Analysis) }\end{array}$ \\
\hline Sunda continental shelf (off Viet Nam, South China Sea) & Kihara and Itosu (1989) & $\begin{array}{l}\text { Season } \\
\text { (temporal), depth }\end{array}$ & Affinity index \\
\hline Indian Ocean coast of Bali to Mid-Sumatra, Indonesia & McManus (1996) & Depth & TWINSPAN, DCA \\
\hline Southwest shelf of Indonesia & McManus (1989) & Depth & TWINSPAN \\
\hline Samar Sea, Philippines & McManus (1986) & Depth & TWINSPAN, DCA \\
\hline Northern continental shelf of South China Sea & Qui (1988) & Depth & $\begin{array}{l}\text { Bray-Curtis measure of } \\
\text { similarity }\end{array}$ \\
\hline Gulf of Thailand (southwestern part of South China Sea) & Suvavepun (1991) & $\begin{array}{l}\text { Temporal, fishing } \\
\text { patterns }\end{array}$ & $\begin{array}{l}\text { Spearman's rank correlation } \\
\text { of principal species groups }\end{array}$ \\
\hline
\end{tabular}

general, these studies have dealt with local or national level analyses of the relationship between environmental parameters and the structure of fish assemblages in the various fishing areas. These studies have also used a wide range of analysis methods (Table 1) making direct comparisons difficult. In most studies, local conditions such as depth, salinity, oxygen depletion and habitat type have been shown to influence the fish assemblage structure (Table 1). However, the regional implications to fisheries management have yet to be given sufficient attention.

Many Asian countries use "fishing zones" as a spatial management tool to restrict fishing in particular areas. These have been established for a range of reasons, including to manage fishing effort or restrict fishing gears to designated areas (Purwanto, 2003), or to avert conflicts that might arise between different fisheries or sectors (e.g. small-scale and commercial sectors) (Barut et al., 2003; Taupek and Nasir, 2003). However, the delineation of these fishing zones is rarely based on a scientific understanding of the spatial structure of the resources. In these cases, the management zones are unlikely to be effective in managing the overall impact from different fisheries on the sustainability of the fish stocks.

Another form of spatial management that has become increasingly common across Asia is the use of marine protected areas (or marine reserves). These can vary from "no take zones" to "multiple-use" areas (Roberts et al., 2001; FAO, 2003; Sale et al., 2005). Marine reserves have been widely promoted as both conservation and fishery management tools, but the fishery benefits remain controversial (Roberts et al., 2001). Again, the underlying assemblage structure is a critical input into the design of a marine reserve, and long-term information on which species persist in reserves of different sizes and assemblage structures is needed to improve their effectiveness (Vanderklift et al., 1998; Botsford et al., 2003).

This paper reviews the results of assemblage structure analyses undertaken within a regional initiative across South and Southeast Asia (Silvestre et al., 2003; Stobutzki et al., 2006). The aim was to examine assemblage structure and infer potential environmental drivers within coastal fishing areas of four countries: Bangladesh, Indonesia, Malaysia, and the Philippines. The analyses use scientific trawl data and standardized analysis techniques to facilitate comparisons and elucidate regional trends in assemblage structure. This is the first time that simultaneous and standardized analyses have been undertaken across multiple countries in the region. Here we present a review of the country-specific and initial regional trends. The critical implications of the spatial structures of fisheries resources to fisheries management and particularly fishing zones are also discussed and we present some topics for future directions for fish assemblage analysis in the region.

\section{Materials and methods}

\subsection{Trawl surveys and data sources}

All data came from scientific trawl surveys (Table 2; Fig. 1) and detailed information of the surveys (i.e., sampling design, 
Table 2

Fishing areas and surveys used for analysis in understanding demersal fish assemblages in South and Southeast Asia

\begin{tabular}{llll}
\hline Country/survey area & Depth $(\mathrm{m})$ & Time period of surveys analyzed & Reference \\
\hline Bangladesh, Inner Bay of Bengal & $10-100$ & 1985 & Mustafa (2003) \\
Indonesia, North Coast of Central Java & $5-50$ & 1979 & Nurhakim (2003) \\
$\begin{array}{l}\text { Malaysia: West Coast Peninsular Malaysia, East Coast } \\
\quad \text { Peninsular Malaysia, Sabah and Sarawak }\end{array}$ & $10-100$ & $1972,1981,1987,1991$ and 1997 & Alias (2003) \\
Philippines & & & Campos (2003) \\
$\quad$ Manila Bay & $10-50$ & $1992-1993$ & $1994-1995$ \\
$\quad$ San Pedro Bay & $10-40$ & $1979-1980$ & \\
$\quad$ Samar Sea & $10-100$ & & \\
$\quad$
\end{tabular}

geographic coverage and gear/trawl characteristics) are given in Mustafa (2003) (Bangladesh), Nurhakim (2003) (Indonesia), Alias (2003) (Malaysia), and Campos (2003) (Philippines). The data available were catch of individual species or taxa at each trawl station. There was no standardization between countries in terms of the taxonomic groupings used in the analyses. The data in each country came from different years and surveys were not carried out across seasons, hence the analyses focused on spatial patterns and not inter-annual or seasonal trends.

In all countries, except for Malaysia, the data analyzed were in the form of catch rate (in $\mathrm{kg} \mathrm{h}^{-1}$ ). For Malaysia, catch per unit area (in $\mathrm{kg} \mathrm{nmile}^{-2}$ ) was used instead of catch rate. This was done to standardize the data sets used for the analysis since the trawl surveys were carried out in various years (i.e., 1972, 1981, 1987, 1991, and 1997) and to account for differences in the survey coverage area including the types of vessel and gear used for the surveys (Alias, 2003). In addi- tion, species or taxa groups were standardized to family level for consistency between the surveys used in the analysis, and station data belonging to the same grid area in one survey period were averaged for each family. This procedure resulted in a reduction in the number of samples (stations) from 1598 stations to 251 stations to suite the limitations of the TWINSPAN software since it can only accommodate a data matrix containing 400 species with 119 stations/sites (Hill, 1979).

This data reduction procedure may result in a generalization of the spatial structure of the fish assemblages with a possible loss of definition of finer scale distribution patterns of species or taxa.

\subsection{Data analysis}

Separate analyses were done for each country, each using the same standardized procedure. Patterns of assemblage

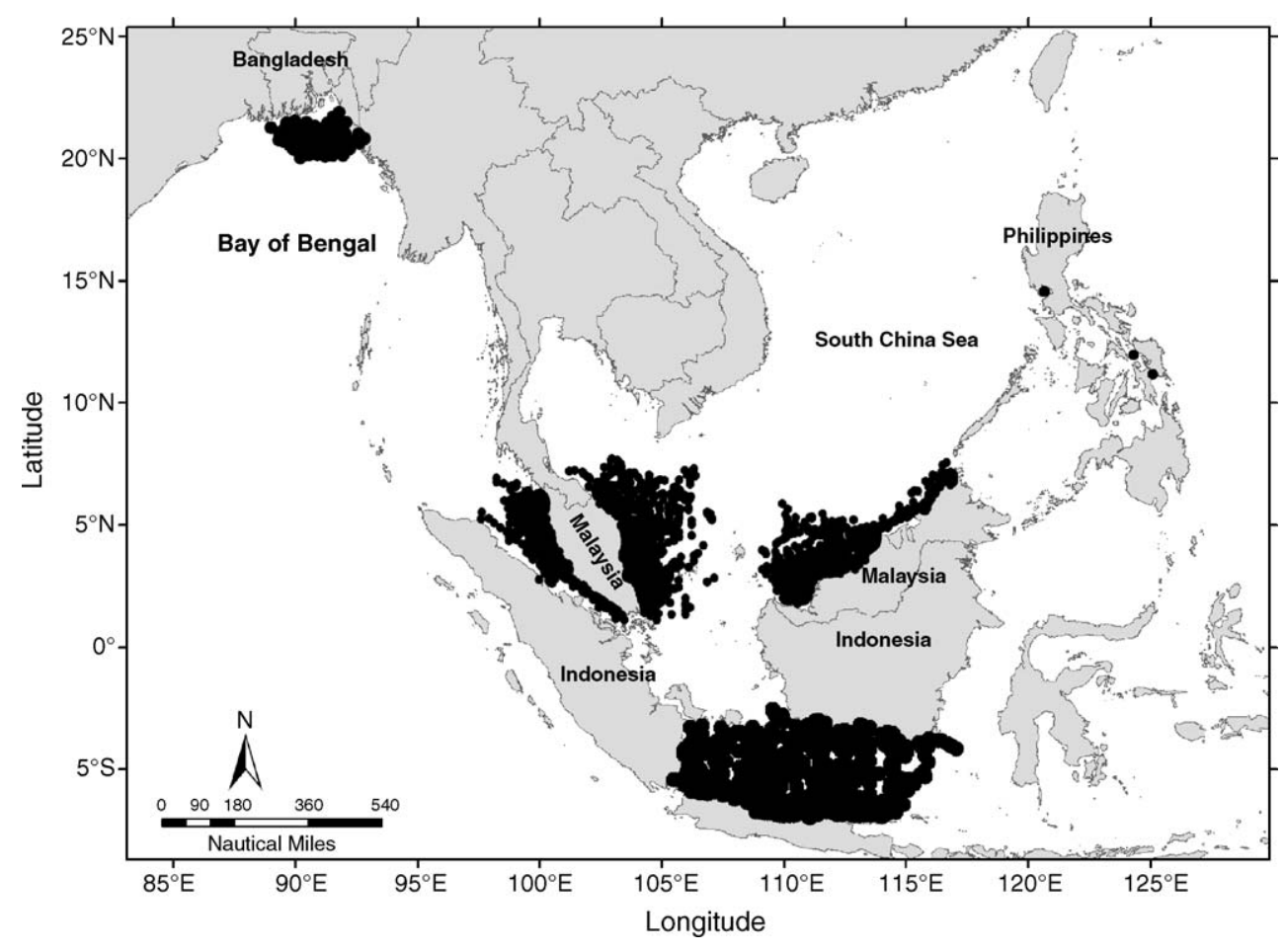

Fig. 1. Locations of study areas (shaded) in Bangladesh, Indonesia, Malaysia, and the Philippines that were analyzed for spatial patterns of demersal fish assemblages. 
structure were analyzed using the divisive classification algorithm Two-way Indicator Species Analysis (TWINSPAN) (Hill, 1979). This technique gives the hierarchical relationship between groups of species or stations. To validate the results of the TWINSPAN an ordination was performed using Detrended Correspondence Analysis (DCA). The classification from TWINSPAN and the ordination from DCA are both based on correspondence analysis (van Groenewoud, 1992).

The TWINSPAN produced two-way tables in which the row (species) arrangement corresponds to the species clusters (species assemblages) and the column (sample = station) arrangement corresponds to the sample clusters (i.e., groups of stations forming habitats). In the process, indicator species are identified which are characteristic of the fish assemblage of each group of sample units or station group (Hill, 1979). Dendrograms were then constructed to provide a visual presentation of the similarity or dissimilarity between the formed clusters. TWINSPAN results are usually reasonable at first division, which would explain the first environmental gradients influencing the assemblage patterns (van Groenewoud, 1992). Hence, in most cases we have presented the assemblage groups defined at the first division. In the analysis results for the Malaysian waters, particularly, Sabah and Sarawak area, the second division groups are presented for better resolution since the geographic coverage of surveys were more extensive than in the other areas.

Ordinations were conducted to verify the classification results. Where necessary, a frequency of occurrence of
5-10\% was used as criteria to limit the number of species included in the analysis. Ordination of samples (stations) in "species space" and species in "sample space" was performed using DCA in the CANOCO program (Ter Braak, 1988). Ordination is a method of plotting samples on a coordinate system representing gradients in species abundance (species space) or plotting species along axes representing station (i.e., habitat or geographic location) preferences (sample space). These plots reveal how distinct (or indistinct) the TWINSPAN-generated clusters were from each other. In all countries, the two techniques, i.e., ordination and clustering, produced consistent assemblage grouping.

The relationship between the observed clustering and ordination pattern and environmental parameters (e.g. depth, salinity, substrate type) was examined visually in the country level analysis. Depth information was available for nearly all trawl survey stations, while salinity and substrate information were only available in general areas. To examine the relationship between depth and the fish assemblage groupings more rigorously, a one-way analysis of variance (ANOVA) (Zar, 1984) was undertaken. The ANOVA compared if the mean depths among the assemblage groupings from the ordinations are significantly different. In Sabah/Sarawak, Malaysia, where there were more than two assemblage groups, the ANOVA was followed by the Duncan's Multiple Range Test (DMRT) (SAS Institute, 1994) to determine which assemblages were significantly different. This analysis was done with the Statistical Analysis System (SAS) software (SAS Institute, 1994).

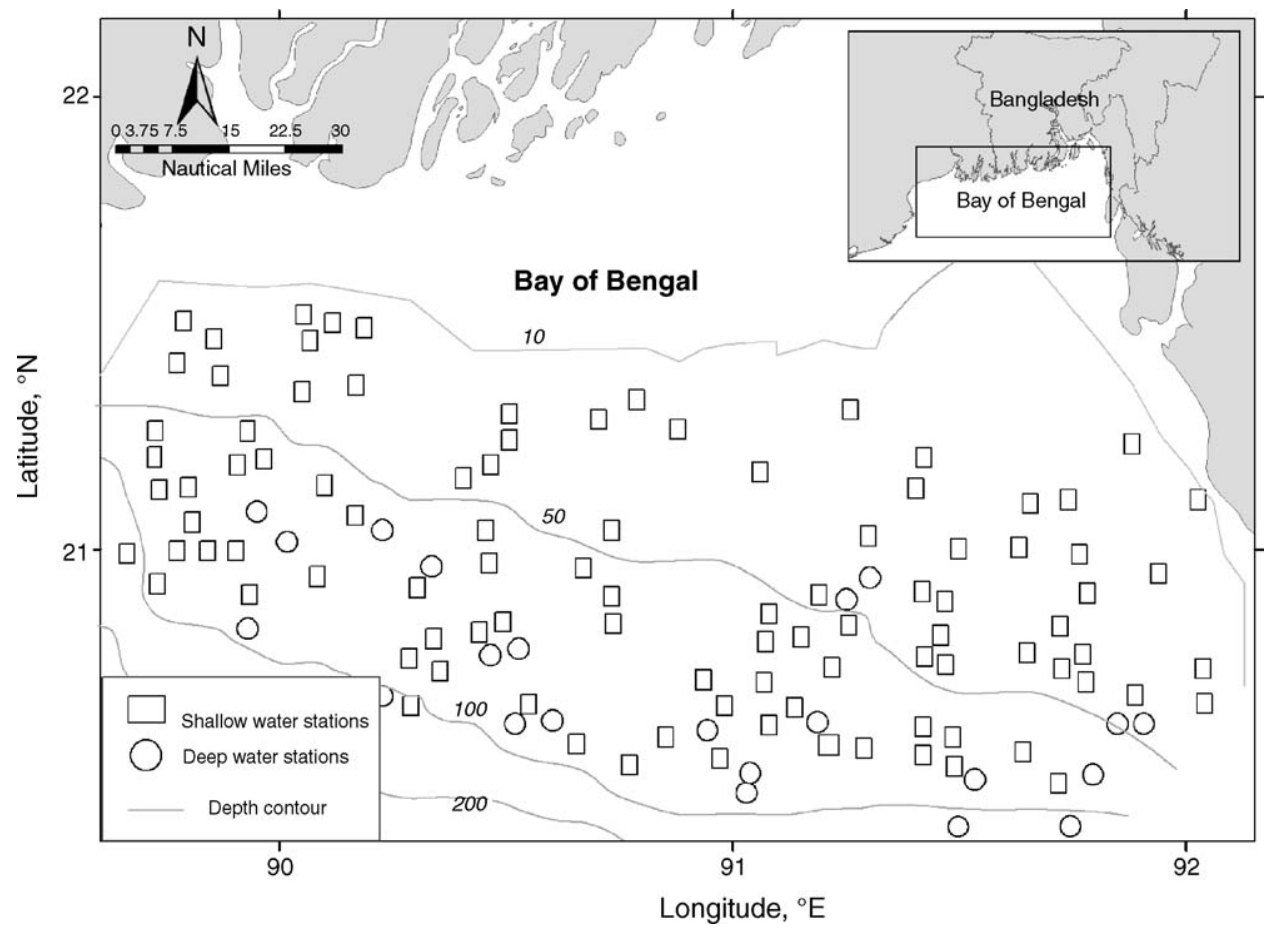

Fig. 2. Map of station locations in the Bay of Bengal, Bangladesh (September 1984-December 1986) showing the geographical delineation of "shallow" and "deep" fish assemblage groups with boundary at approximately $90 \mathrm{~m}$ depth contour. Depth is shown in meters (Source: Mustafa, 2003). 


\section{Results}

\subsection{Bangladesh}

The Bay of Bengal waters in Bangladesh showed two assemblage groups. The fishing stations did not show clear delineation between the "shallow-" and "deep-" water assemblages (Fig. 2). However, the mean depths of the "shallow" and "deep" assemblages were significantly different
(Table 3). The "shallow" stations were characterized by higher abundances of Nemipterus japonicus, Lepturacanthus savala, Pennahia spp., Pentaprion longimanus, Upeneus spp., Arius spp., Pomadasys maculatus, Thryssa brevirostris, Leiognathus bindus, Rastrelliger kanagurta, Leiognathus spp. and Upeneus sulphureus (Table 4). The "deep" stations were characterized by higher abundances of Priacanthus hamrur, Priacanthus spp., Johinus spp., Saurida elongata and Nemipterus spp.

Table 3

The average depth and S.E. of stations in each fish assemblage group in each region

\begin{tabular}{|c|c|c|c|c|c|c|c|}
\hline Country/survey area & Assemblage groups & Stations $(n)$ & Average depth (m) & S.E. & d.f. & $F$ & $P$-value \\
\hline \multirow[t]{2}{*}{ Bangladesh: Inner Bay of Bengal } & Shallow & 135 & 71.27 & 2.43 & \multirow[t]{2}{*}{1,156} & \multirow[t]{2}{*}{12.48} & \multirow[t]{2}{*}{$<0.001$} \\
\hline & Deep & 23 & 92.35 & 2.05 & & & \\
\hline \multirow[t]{2}{*}{ Indonesia: North Coast of Central Java } & Shallow & 6 & 11.67 & 2.47 & \multirow[t]{2}{*}{1,16} & \multirow[t]{2}{*}{15.52} & \multirow[t]{2}{*}{$<0.001$} \\
\hline & Deep & 12 & 27.42 & 2.34 & & & \\
\hline \multirow[t]{2}{*}{ Malaysia: West Coast Peninsular } & Shallow & 32 & 28.75 & 1.27 & \multirow[t]{2}{*}{1,125} & \multirow[t]{2}{*}{147.65} & \multirow[t]{2}{*}{$<0.001$} \\
\hline & Deep & 95 & 59.53 & 1.40 & & & \\
\hline \multirow[t]{3}{*}{ Malaysia: Sabah and Sarawak } & Shallow $^{\mathrm{a}}$ & 128 & 29.93 & 0.62 & \multirow[t]{3}{*}{2,378} & \multirow[t]{3}{*}{915.24} & \multirow[t]{3}{*}{$<0.001$} \\
\hline & Intermediate $\mathrm{a}^{\mathrm{a}}$ & 178 & 60.25 & 1.06 & & & \\
\hline & Deep $^{a}$ & 75 & 114.64 & 2.25 & & & \\
\hline \multirow[t]{2}{*}{ Philippines: Manila Bay } & Shallow & 9 & 12.78 & 2.52 & \multirow[t]{2}{*}{1,14} & \multirow[t]{2}{*}{7.85} & \multirow[t]{2}{*}{$<0.01$} \\
\hline & Deep & 7 & 27.14 & 4.86 & & & \\
\hline \multirow[t]{2}{*}{ Philippines: Samar Sea } & Shallow & 11 & 33.18 & 2.95 & \multirow[t]{2}{*}{1,26} & \multirow[t]{2}{*}{29.93} & \multirow[t]{2}{*}{$<0.001$} \\
\hline & Deep & 17 & 64.41 & 4.15 & & & \\
\hline \multirow[t]{2}{*}{ Philippines: San Pedro Bay } & Shallow & 6 & 13.33 & 1.05 & \multirow[t]{2}{*}{1,11} & \multirow[t]{2}{*}{53.71} & \multirow[t]{2}{*}{$<0.001$} \\
\hline & Deep & 7 & 27.14 & 1.60 & & & \\
\hline
\end{tabular}

The results of the one-way ANOVA's comparing depth among assemblage groups are also shown. (Note: refer to Fig. 10 and text for assemblage groups by survey area.)

a Assemblages groups are significantly different $(P<0.001)$ based on Duncan's Multiple Range Test, see notations on average depth.

Table 4

Distribution of dominant species/taxa comprising the "shallow" and "deep" demersal fish assemblages in South and Southeast Asia

\begin{tabular}{|c|c|c|c|c|c|c|c|c|c|c|c|c|c|c|}
\hline \multirow[t]{2}{*}{ Taxa/Species } & \multicolumn{7}{|c|}{ "Shallow" fish assemblage } & \multicolumn{7}{|c|}{ "Deep" fish assemblage } \\
\hline & BB & NJI & WPM & SSM & MBP & SBP & SSP & BB & NJI & WPM & SSM & MBP & SBP & SSP \\
\hline Ariidae & $\mathrm{X}$ & & & $\mathrm{X}$ & & & & & & & $\mathrm{X}$ & & & \\
\hline \multicolumn{15}{|l|}{ Balistidae } \\
\hline Abalistes stellatus & & & & & & & & & $\mathrm{X}$ & & $\mathrm{X}$ & & & \\
\hline Carangidae & & & $X$ & $\mathrm{X}$ & & & & & & & $\mathrm{X}$ & & & \\
\hline Alectis ciliaris & & & & & & & & & & & & $\mathrm{X}$ & & \\
\hline A. indicus & & & & & & $X$ & & & & & & & & \\
\hline Carangoides armatus & & & & & & & $X$ & & & & & & & \\
\hline Decapterus kurroides & & & & & & & & $\mathrm{X}$ & & & $\mathrm{X}$ & & & \\
\hline Selaroides leptolepis & & & & & & & & & & & & $\mathrm{X}$ & & \\
\hline Clupeidae & & & & $\mathrm{X}$ & & & & & & & $\mathrm{X}$ & & & \\
\hline Anodontostoma spp. & & $\mathrm{X}$ & $\mathrm{X}$ & $\mathrm{X}$ & & & & & & & & & & \\
\hline Dussumieria elopsoides & & & $\mathrm{X}$ & & & & & & & & & & & \\
\hline Dasyatidae & $\mathrm{X}$ & & & & & & & & & & $\mathrm{X}$ & & & \\
\hline Drepaneidae & & & & & & & & & $\mathrm{X}$ & & & & & \\
\hline Engraulidae & & $\mathrm{X}$ & & & & & & & & & & & & \\
\hline Stolephorus bataviensis & & & & & $X$ & & & & & & & & & \\
\hline S. commersonnii & & & & & $X$ & & & & & & & & & \\
\hline S. indicus & & & & & & & & & & & & $\mathrm{X}$ & & \\
\hline Gerreidae & & $\mathrm{X}$ & & & & & $\mathrm{X}$ & & & $\mathrm{X}$ & & & & \\
\hline
\end{tabular}


Table 4 (Continued)

\begin{tabular}{|c|c|c|c|c|c|c|c|c|c|c|c|c|c|c|}
\hline \multirow[t]{2}{*}{ Taxa/Species } & \multicolumn{7}{|c|}{ "Shallow" fish assemblage } & \multicolumn{7}{|c|}{ "Deep" fish assemblage } \\
\hline & $\mathrm{BB}$ & NJI & WPM & SSM & MBP & SBP & SSP & $\mathrm{BB}$ & NJI & WPM & SSM & MBP & SBP & SSP \\
\hline $\begin{array}{l}\text { Haemulidae } \\
\text { Pomadasys maculatus } \\
\text { Pomadasys spp. }\end{array}$ & $\mathrm{X}$ & & & & & & & & $\mathrm{X}$ & & & & & \\
\hline $\begin{array}{l}\text { Leiognathidae } \\
\text { Leiognathus bindus } \\
\text { L. elongatus } \\
\text { Leiognathus equulus } \\
\text { L. splendens }\end{array}$ & & & $\mathrm{X}$ & $\mathrm{X}$ & & & $\begin{array}{l}X \\
X\end{array}$ & & & $X$ & & $\mathrm{X}$ & & \\
\hline Loliginidae (Squids) & & & $\mathrm{X}$ & & & & & & & & & & & \\
\hline Lutjanidae & & & & & & & & & $\mathrm{X}$ & $\mathrm{X}$ & & & & \\
\hline $\begin{array}{l}\text { Mugilidae } \\
\quad \text { Mugil cephalus } \\
\text { Valamugil seheli }\end{array}$ & & & & & $\begin{array}{l}X \\
X\end{array}$ & & & & & & & & & \\
\hline $\begin{array}{l}\text { Mullidae } \\
\text { Upeneus sulphureus } \\
\text { U. tragula }\end{array}$ & $\mathrm{X}$ & & $\mathrm{X}$ & $\mathrm{X}$ & & & & & & $\mathrm{X}$ & $\mathrm{X}$ & $\mathrm{X}$ & & \\
\hline Muraenesocidae & & $\mathrm{X}$ & & & & & & & & & & & & \\
\hline $\begin{array}{l}\text { Nemipteridae } \\
\quad \text { Nemipterus japonicus }\end{array}$ & $\mathrm{X}$ & & & $\mathrm{X}$ & & & & $\begin{array}{l}X \\
X\end{array}$ & $\mathrm{X}$ & $\mathrm{X}$ & $\mathrm{X}$ & & & $\mathrm{X}$ \\
\hline $\begin{array}{l}\text { Platycephalidae } \\
\text { Elates ransonnetii }\end{array}$ & & & & & & & & & & & & & $\mathrm{X}$ & \\
\hline $\begin{array}{l}\text { Polynemidae } \\
\quad \text { Eleutheronema tetradactylum }\end{array}$ & & & & & $\mathrm{X}$ & & & & & & & & & \\
\hline Pomacentridae & & & & & & & & & & & & $\mathrm{X}$ & & \\
\hline $\begin{array}{l}\text { Priacanthidae } \\
\text { Priacanthus hamrur } \\
\text { P. macracanthus } \\
\text { Priacanthus spp. } \\
\text { Priacanthus tayenus }\end{array}$ & & & & & & & & $\mathrm{X}$ & & $\mathrm{X}$ & $\mathrm{X}$ & $\mathrm{X}$ & $\mathrm{X}$ & $\mathrm{X}$ \\
\hline $\begin{array}{l}\text { Sciaenidae } \\
\text { Johnius spp. } \\
\text { Pennahia macropthalmus }\end{array}$ & $\mathrm{X}$ & $\mathrm{X}$ & & $\mathrm{X}$ & $\begin{array}{l}X \\
X\end{array}$ & & & $\mathrm{X}$ & & & & & & \\
\hline $\begin{array}{l}\text { Scombridae } \\
\quad \text { Rastrelliger kanagurta } \\
\text { Scomberomorus commerson }\end{array}$ & $\mathrm{X}$ & & $\mathrm{X}$ & & $\mathrm{X}$ & & & & & & & & & \\
\hline Sphyraenidae (Sharks) & & & & & & & & & $\mathrm{X}$ & & $\mathrm{X}$ & & & \\
\hline $\begin{array}{l}\text { Sillaginidae } \\
\quad \text { Sillago sihama }\end{array}$ & & & & & $\mathrm{X}$ & & & & & & & & & \\
\hline $\begin{array}{l}\text { Synodontidae } \\
\text { Saurida elongata } \\
\text { Saurida spp. } \\
\text { Synodus variegatus }\end{array}$ & & & & & & & & $\mathrm{X}$ & & & $\begin{array}{l}X \\
X\end{array}$ & $\mathrm{X}$ & $\mathrm{X}$ & \\
\hline $\begin{array}{l}\text { Tetraogidae } \\
\quad \text { Neocentropogon aeglefinis }\end{array}$ & & & & & & & & & & & $\mathrm{X}$ & & & \\
\hline $\begin{array}{l}\text { Triacanthidae } \\
\text { Pseudotriacanthus strigilifer }\end{array}$ & & & & & & X & & & & & & & & \\
\hline
\end{tabular}

Trichiuridae

Lepturacanthus savala $\quad \mathrm{X}$

Trichiurus haumela

$\mathrm{X}$ Trichiurus spp.

$\mathrm{X} \quad \mathrm{X}$

$\mathrm{X}$

Note: BB-Bay of Bengal, Bangladesh; NJI—north coast of Java, Indonesia; WPM—West coast, Peninsular Malaysia; SSM—Sabah and Sarawak, Malaysia; MBP—Manila Bay, Philippines; SBP—San Pedro Bay, Philippines; SSP—Samar Sea, Philippines; X—higher abundance. 


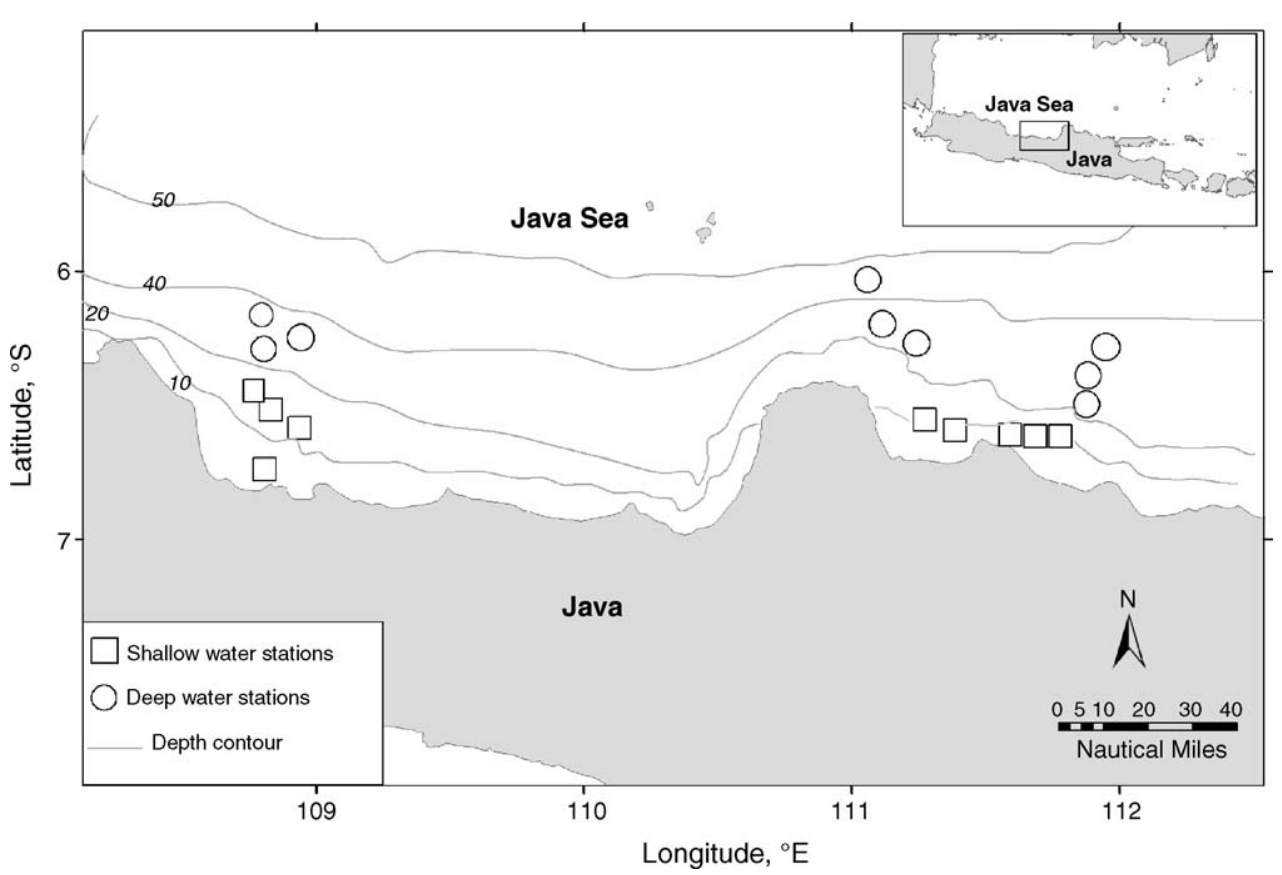

Fig. 3. Map of station cluster locations in Java Sea, Indonesia (January-February 1979) showing the geographical delineation of "shallow" and "deep" fish assemblage groups with the boundary at approximately $20 \mathrm{~m}$ depth contour. Depth is shown in meters (Source: Nurhakim, 2003).

\subsection{Indonesia}

Two distinct groups of stations were clearly evident from the analysis in the Java Sea, Indonesia, delineated at $20 \mathrm{~m}$ depth (Fig. 3). The mean depth was significantly different between the two assemblage groups (Table 3). There were notable differences in species composition between the "shallow" and "deep" stations. For example, Sciaenidae, Muraenidae and Anodontostoma spp. were more abundant in "shallow" water stations while Priacanthus spp., P. longimanus, Sphyraenidae, Arius thalassinus and N. japonicus were more abundant in “deep" stations (Table 4).

\subsection{Malaysia}

The assemblage structure analysis of demersal fish resources in Malaysian waters showed varied results depending on the geographical location. On the west coast of Peninsular Malaysia, there were two (i.e., "shallow" and "deep") assemblage groups, delineated at $50 \mathrm{~m}$ depth contour (Fig. 4). On the east coast of Peninsular Malaysia, there was a single assemblage group, which corresponded to the "deep" assemblage of the west coast. There were clear differences in the assemblage groups between Peninsular Malaysia and Sabah and Sarawak areas. In Sabah and Sarawak waters there were three assemblage groups (Fig. 5). The "shallow" group was delineated at $50 \mathrm{~m}$ depth, the "deep" group $>100 \mathrm{~m}$, and an "intermediate" group between 50 and $100 \mathrm{~m}$. It must be noted that the sampling extended to greater depths (up to $185 \mathrm{~m}$ ) in Sabah and Sarawak waters than in Peninsular Malaysia (<100 m depth in most stations). Depth differed significantly between the assemblage groups in west coast Peninsular Malaysia as well as in the three assemblages in Sabah and Sarawak waters (Table 3). In terms of species composition, on the west coast of Peninsular Malaysia and in Sabah and Sarawak waters Anodontostoma spp., Clupeidae, and Sciaenidae were more abundant in "shallow" stations while Lutjanus spp., Dasyatidae and sharks were more abundant in "deep" stations (Table 4).

\subsection{Philippines}

Three fishing areas were analyzed to understand demersal fish assemblages in the Philippines, namely, the Samar Sea, San Pedro Bay and Manila Bay. San Pedro Bay showed "shallow" and "deep" assemblages with the transition at depths of 15-20 m (Fig. 6). Manila Bay also showed two assemblage groups that appear to be associated with depth, with a transition zone at $40 \mathrm{~m}$ depth (Fig. 7). In the Samar Sea, there were also "shallow" and "deep" assemblage groups delineated at 40-50 m (Fig. 8). The "shallow" and "deep" assemblage groups in all of the three study sites in the Philippines were significantly different in depth (Table 3). Priacanthus spp. were also abundant in "deep" stations in the three fishing areas studied (Table 4).

\section{Discussion}

The analyses of trawl surveys in the fishing areas in the South and Southeast Asian countries examined here indicate spatial structuring of the fish assemblages that appears 


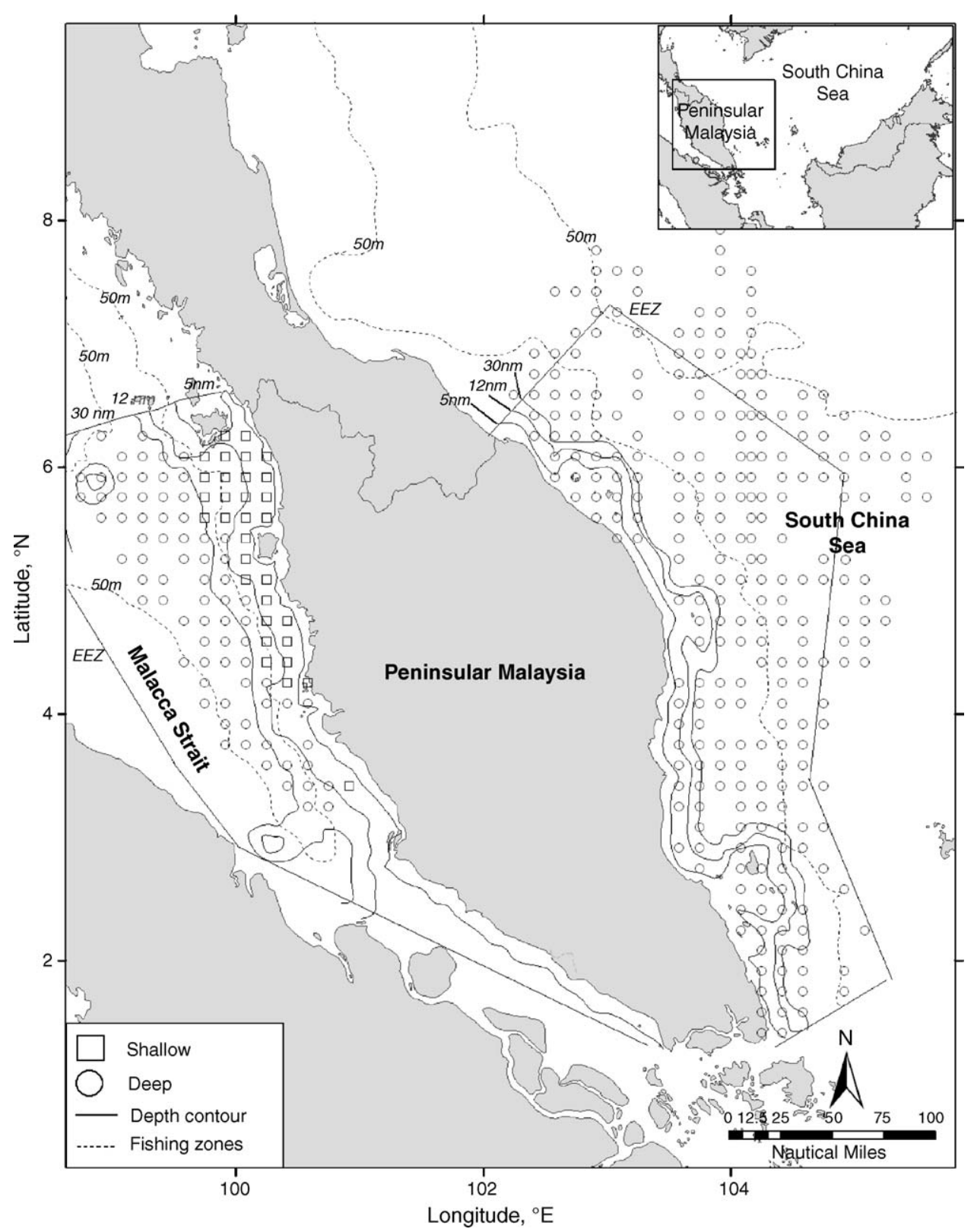

Fig. 4. Map of Peninsular Malaysia showing the geographical delineation of "shallow" (1) and "deep" (2) fish assemblage groups in the west coast with the boundary at approximately $40 \mathrm{~m}$ depth contour and a single assemblage in the east coast (Source: Alias, 2003). Fisheries management zones in Peninsular Malaysia are also given; the outer boundary represents the EEZ (Source: Saharuddin, 1995).

to be influenced by depth (Fig. 9; Table 3). In relatively shallow coastal areas less than $90 \mathrm{~m}$ deep two assemblage groups emerge, delineated at $30-50 \mathrm{~m}$. This spatial delineation is consistent with earlier studies (Fig. 10) in the Samar Sea, Philippines (McManus, 1986), Ragay Gulf, Philippines (Federizon, 1992) and northeast coast of Sumatra, Indonesia (Bianchi et al., 1996). For fishing areas deeper than $100 \mathrm{~m}$ such as in coastal waters off Sabah and Sarawak, Malaysia, three assemblages were observed: shallow $(<50 \mathrm{~m})$, deep $(>100 \mathrm{~m})$ and intermediate $(50-100 \mathrm{~m})$. Again, this finding is comparable with an earlier study in the northern continental shelf of the South China Sea with delineation at 40,
40-100, 100-200 m (Qui, 1988). Analyses of the catches of 31 of the most common species in a relatively unexploited system in the Gulf of Carpentaria, Australia also indicated that depth strongly affected the abundances of 23 out of 31 species studied (Blaber et al., 1990).

The critical implication of these spatial patterns of demersal fisheries resources is their relationship to existing management zones (Table 5). For example, the waters off Malaysia are subdivided into four zones based on distance from the coastline: Zone A $(0-5 \mathrm{~nm})$, Zone B $(5-12 \mathrm{~nm})$, and Zone $\mathrm{C}(12-30 \mathrm{~nm}$ ), and Zone D (offshore waters extending to the Exclusive Economic Zone boundary) (Saharuddin, 1995). 


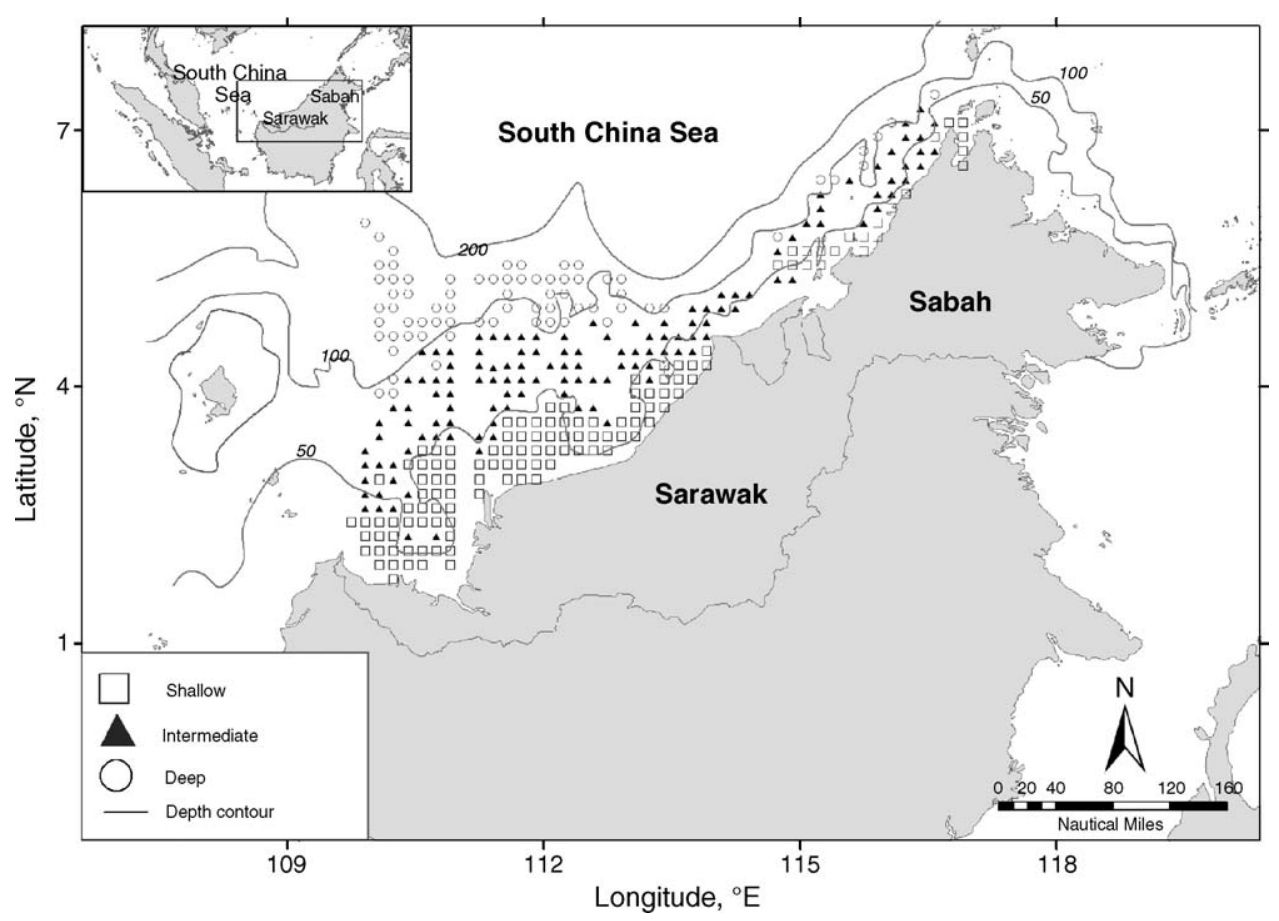

Fig. 5. Map of Sabah and Sarawak Malaysia showing the geographical delineation of "shallow", intermediate, and "deep" fish assemblage groups and delineated at approximately $50 \mathrm{~m}$ depth and $100 \mathrm{~m}$ depth contour, respectively (Source: Alias, 2003).

The existing spatial fisheries management zones are largely inconsistent with the assemblage structure patterns observed in our study. For example, Fig. 4 shows the demersal fish assemblages in Peninsular Malaysia waters based on the analyses and the current management zones being applied to partition fishing effort/gear in the same area. In the case of the Philippines, fisheries are legally categorized into municipal and commercial sectors: the commercial sector is excluded from fishing within $15 \mathrm{~km}$ from the shore (Barut et al., 2003). The results of the analyses in three fishing areas: Samar Sea, San Pedro Bay and Manila Bay also indicate that current management zones may not be consistent with the assemblage patterns. It is clear that the demersal fish assemblages go across the management zones and so while different sectors may be segregated spatially they are still potentially fishing the same assemblages and possibly stocks.

Currently, Bangladesh, India, Cambodia and Vietnam have existing management zones based on depth of fishing ground (Table 5). In Cambodia, coastal and commercial fisheries are delineated at $20 \mathrm{~m}$ depth, while in Bangladesh artisanal (small-scale) and commercial fisheries are partitioned at $40 \mathrm{~m}$ depth. In the southern sector of India fishing zones in the coastal area are delineated at 32,40 , and $70 \mathrm{~m}$. In Vietnam small- and large-scale fisheries are delineated at $30-50 \mathrm{~m}$. The general spatial trends from this study indicated that at this depth range (30-50 m), the "shallow" and "deep" assemblages are delineated and this is consistent with the Vietnamese fishing zones. The Indian fishing zone with specific vessel and gear categories assigned to each zone could also be used as a possible option to partition coastal fisheries (Table 5).

There are no clear patterns in the composition of species/taxa on the assemblage groups (Table 4) since there was no standardization between countries in terms of the taxonomic groupings. However, initial trends indicate some species/taxa such as Sciaenidae and Anodontostoma spp. are more abundant in "shallow" stations while "deep" stations are characterized by higher abundances of Abalistes stellatus, Lutjanidae, Nemipteridae, Saurida spp., Priacanthus spp. and Trichiurus spp. In an earlier study in the Samar Sea, Philippines, Leiognathus splendens and L. equulus were suggested as characteristic of a "shallow" subcommunity while "deep" stations characteristically include Saurida undosquamis, Nemipterus nematophorus and Priacanthus macracanthus (McManus, 1986). The results from the current study showed similar species/taxa assemblages for "deep" stations in most of the study areas, however Leiognathus spp. showed no clear patterns. In an earlier study on the distribution of leiognathids in Gulf of Carpentaria, Australia (Staunton-Smith et al., 1999), Gazza minuta, Leiognathus decorus, L. equulus, L. fasciatus, L. leuciscus, L. smithursti, $L$. splendens, and Secutor ruconius were found to be restricted to coastal areas, whereas L. bindus, L. moretoniensis, Leiognathus sp. and $S$. insidiator were not.

The trends in species composition may also be influenced by habitat structure or substrate. For example, it was noted that on muddy, inshore ("shallow") grounds on Indo-Pacific shelves, where water tends to be turbid, Sciaenidae are more 


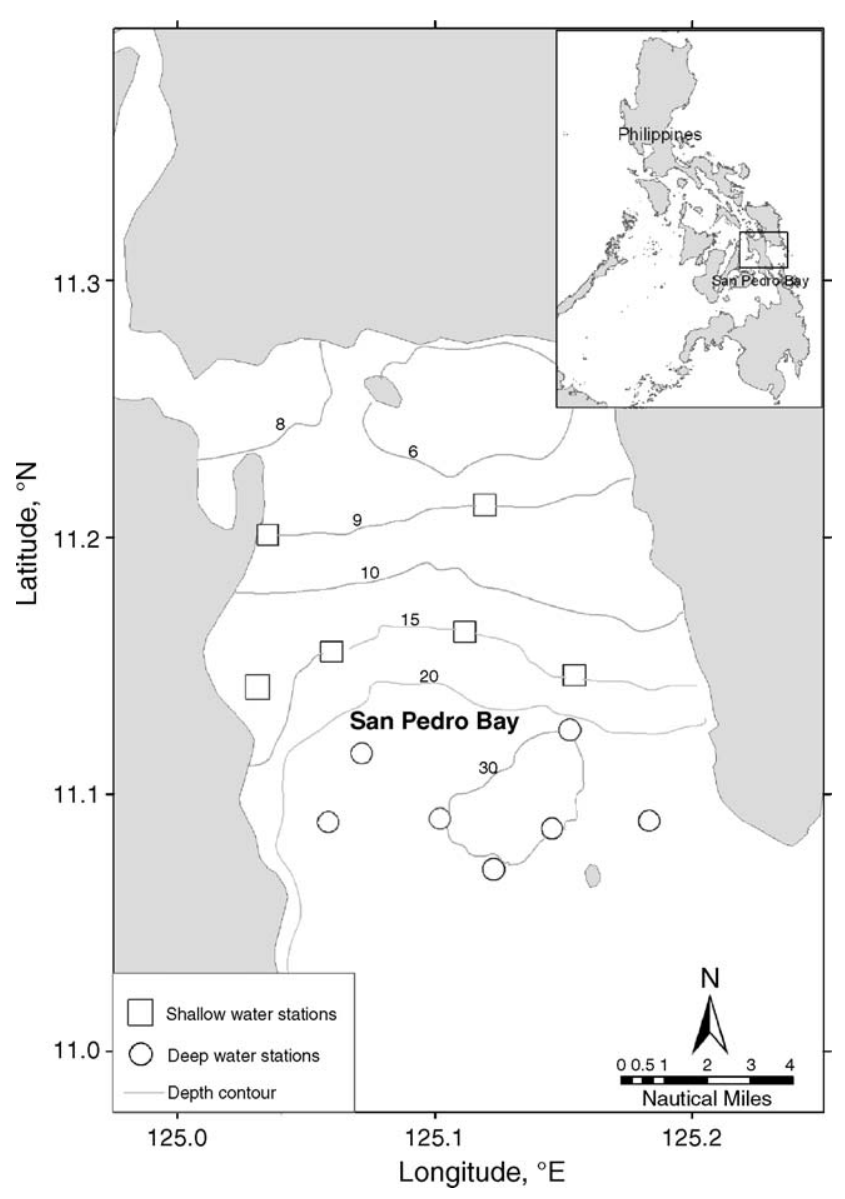

Fig. 6. Map of station cluster locations in San Pedro Bay, Philippines (1994-1995) showing the geographical delineation of "shallow" and "deep" station groups with the boundary at $20 \mathrm{~m}$ depth contour. Depth is shown in meters (Source: Campos, 2003).

abundant while Pricanthidae, Nemipteridae, Mullidae, Gerridae and Leiognathidae are commoner on sandy grounds (Longhurst and Pauly, 1987). Substrate type could then possibly explain the differences in the four assemblage groupings and between the east and west coast of Peninsular Malaysia. Alias (2003) suggests that the lack of significant coastal mangrove communities on the east coast may be the reason for the lack of a distinct "shallow" assemblage. In addition, Federizon (1992) concluded in the case of Ragay Gulf, Philippines that shallow areas could be further divided into those with soft-bottom and coralline substrate. Moreover, substrate type would have an interaction with depth and distance from the shore. In future analyses of assemblage structure, there is a need to standardize the species groupings across countries to be able to better understand the trends in species/taxa in association with the assemblage groups.

In addition, quantitative analyses with other environmental parameters apart from depth, need to be conducted. Earlier work by Bianchi (1996) and McManus (1996) using the same multivariate methods as the current study (TWINSPAN and DCA) to look at demersal fish assemblages in the eastern Indian Ocean, concluded that salinity, bottom type and depth

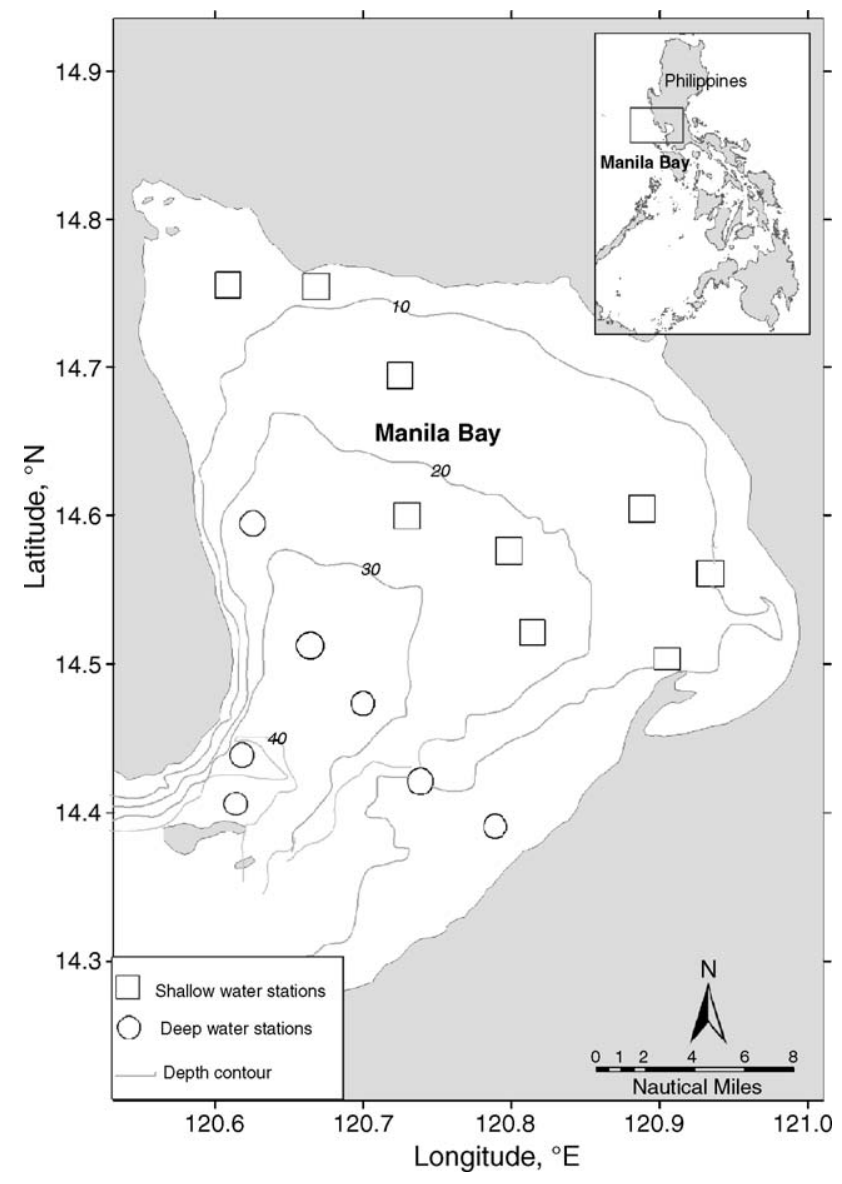

Fig. 7. Map of station cluster locations in Manila Bay, Philippines (1992-1993) showing the geographical delineation of "shallow" and "deep" station groups with the boundary at 20-30 m depth contour. Depth is shown in meters (Source: Campos, 2003).

were the main structuring factors. The relatively unclear transition in the Bay of Bengal (Bangladesh) could be due to oceanographic characteristics such as salinity since it is influenced by a large volume of river discharge (from the Ganges, Brahmaputra and Meghna rivers) into the Bay of Bengal (Mustafa, 2003). Moreover, there were differences in the species composition between inner (southern) and outer (northern) stations in "deep" stations in the Samar Sea, Philippines (Campos, 2003). The differences in the species composition in the "deep" stations could be attributed also to differences in habitat or substrate type, salinity structure and other physical characteristics (i.e., wave action) of the fishing grounds (e.g. Manila Bay and San Pedro Bay) resulting in two assemblage groups.

Apart from spatial structure, there is also a need to look into the temporal stability of the assemblages. Inter-annual trends in species/taxa assemblages were reported within each of the countries studied here (Alias, 2003; Campos, 2003; Nurhakim, 2003; Srinath et al., 2003). However, we could not compare temporal trends as trawl data in the different coastal fishing areas and the countries covered came from different years and seasons. Preliminary results from the Philippines 


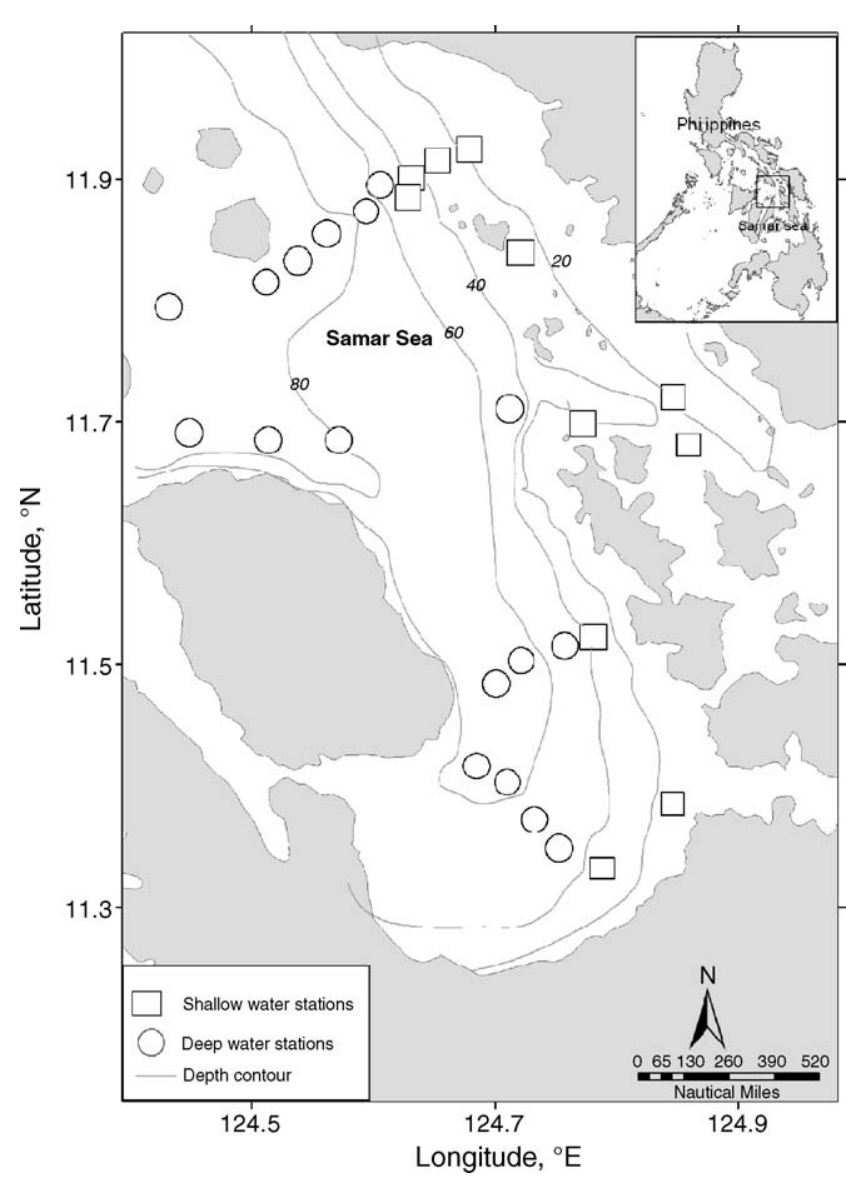

Fig. 8. Map of station cluster locations in Samar Sea, Philippines (March 1979-May 1980) showing the geographical delineation of "shallow" and "deep" station groups with the boundary at 30-40 m depth contour. Depth is shown in meters (Source: Campos, 2003).

indicated that the deeper boundaries (e.g. 40-60 m) were temporally stable and that the shallower depths $(10-30 \mathrm{~m})$ were seasonally influenced (Campos, 2003). This is consistent with the limited number of assemblage structure studies conducted previously in the region (Federizon, 1992; Bianchi, 1996;
McManus, 1996). In addition, potential effects of the monsoon system on the distribution of demersal resources need further understanding (Campos, 2003). Before management zones can be based on the assemblage structure, there is a need to understand the temporal stability of these assemblages. Data availability could be a constraint for this type of analysis since fishing usually ceases during monsoon seasons as well as the conduct of scientific trawl surveys.

Assemblage analyses could also provide insights into the human-induced changes (which include the impact due to fishing), the duration of impact, and the succeeding recovery of the communities (Watson et al., 1990). The assemblages examined here have all been subject to fishing and other human impacts. The extent of influence of this on the detected structure is unknown. In an earlier study in the Gulf of Thailand, it has been shown that fishing can affect, directly or indirectly, the structure of fish assemblages (Suvavepun, 1991). In addition, heavy fishing pressure may have changed the species composition of demersal fish communities and the macrobenthos (Kongprom et al., 2003; Christensen, 1998). Evidence for massive changes in species composition in the Gulf of Thailand was obtained from analysis of trawl survey data between 1963 and 1972 (Pauly, 1988). The study noted a faster decrease in abundance of Leiognathidae and some other small fishes as well as virtual disappearance of Pristidae and Dasyatidae (i.e., very large, long-lived fish). Temporal analyses of the assemblage structure, where data are available from prior to or the early years of fishing, would help elucidate the changes that have occurred.

In current study, the multivariate techniques were standardized across the countries to allow comparisons. However, this restricted the approaches that could be used and therefore limits the results obtained. TWINSPAN analysis, has been noted to be most reliable for the first division and should be restricted to sampling across a single gradient or prestratifying the samples (or stations) to represent one gradient at a time (van Groenewoud, 1992). In some of the country analyses, for example, Java Sea (Nurhakim, 2003), the

\begin{tabular}{|l|l|l|l|l|l|l|l|l|l|l|}
\hline \multirow{2}{*}{$\begin{array}{l}\text { Coastal Areas } \\
\text { (Source) }\end{array}$} & \multicolumn{7}{|c|}{ Major assemblages (by depth range - m) } \\
\hline & $<10$ & 20 & 30 & 40 & 50 & 60 & 70 & 80 & 90 & $>100$ \\
\hline $\begin{array}{l}\text { Bangladesh - Bay of Bengal } \\
\text { (Mustafa, 2003) }\end{array}$ & & & & & & & & & & \\
\hline $\begin{array}{l}\text { Indonesia - North coast of Java } \\
\text { (Nurhakim, 2003) }\end{array}$ & & & & & & & & & & \\
\hline $\begin{array}{l}\text { Malaysia - Sabah/Sarawak waters } \\
\text { (Alias, 2003) }\end{array}$ & & & & & & & & & & \\
\hline $\begin{array}{l}\text { Malaysia - Peninsular, West Coast } \\
\text { (Alias, 2003) }\end{array}$ & & & & & & & & & & \\
\hline $\begin{array}{l}\text { Malaysia - Peninsular, East Coast } \\
\text { (Alias, 2003) }\end{array}$ & & & & & & & & & & \\
\hline $\begin{array}{l}\text { Philippines - Manila Bay } \\
\text { (Campos, 2003) }\end{array}$ & & & & & & & & & & \\
\hline $\begin{array}{l}\text { Philippines - San Pedro Bay } \\
\text { (Campos, 2003) }\end{array}$ & & & & & & & & & & \\
\hline $\begin{array}{l}\text { Philippines - Samar Sea } \\
\text { (Campos, 2003) }\end{array}$ & & & & & & & & & \\
\hline
\end{tabular}

Fig. 9. Summary of the major fish assemblage boundaries observed from assemblage structure analysis in South and Southeast Asia. The different shading in each area depicts the different fish assemblages from the analyses. Depth ranges with no shading were not covered by the survey or analysis (Mustafa, 2003; Nurhakim, 2003; Alias, 2003; Campos, 2003). 


\begin{tabular}{|c|c|c|c|c|c|c|c|c|c|c|c|c|}
\hline \multirow{2}{*}{$\begin{array}{l}\text { Coastal Areas } \\
\text { (Source) }\end{array}$} & \multicolumn{12}{|c|}{ Major assemblages (by depth range $-m$ ) } \\
\hline & $<10$ & 10 & 20 & 30 & 40 & 50 & 60 & 70 & 80 & 90 & 100 & $>100$ \\
\hline \multicolumn{13}{|l|}{$\begin{array}{l}\text { Brunei Darussalam } \\
\text { (Silvestre et al., 2003) }\end{array}$} \\
\hline \multicolumn{13}{|c|}{$\begin{array}{l}\text { Indonesia - Northwest Coast of } \\
\text { Sumatra } \\
\text { (Bianchi, 1996) }\end{array}$} \\
\hline \multicolumn{13}{|c|}{$\begin{array}{l}\text { Indonesia - Java Sea, including } \\
\text { part of southern South China Sea } \\
\text { (Bianchi et al., 1996) }\end{array}$} \\
\hline \multicolumn{13}{|c|}{$\begin{array}{l}\text { Indonesia - Southwest Shelf } \\
\text { (Java) } \\
\text { (McManus, 1989) }\end{array}$} \\
\hline \multicolumn{13}{|l|}{$\begin{array}{l}\text { Indian Ocean - coast of Bali to } \\
\text { mid-Sumatra } \\
\text { (McManus, 1996) }\end{array}$} \\
\hline \multicolumn{13}{|l|}{$\begin{array}{l}\text { India - West Coast } \\
\text { (Srinath et al., 2003) }\end{array}$} \\
\hline \multicolumn{13}{|l|}{$\begin{array}{l}\text { Pakistan Shelf } \\
\text { (Bianchi, 1992) }\end{array}$} \\
\hline \multicolumn{13}{|l|}{$\begin{array}{l}\text { Philippines - Samar Sea } \\
\text { (McManus, 1986) }\end{array}$} \\
\hline \multicolumn{13}{|l|}{$\begin{array}{l}\text { Philippines - Ragay Gulf } \\
\text { (Federizon, 1992) }\end{array}$} \\
\hline \multicolumn{13}{|c|}{$\begin{array}{l}\text { Gulf of Thailand - Eastern part off } \\
\text { Chanthaburi } \\
\text { (Chittima and Wannakiat, 1992) }\end{array}$} \\
\hline \multicolumn{13}{|c|}{$\begin{array}{l}\text { Gulf of Thailand } \\
\text { (Khongchai et al., 2003) }\end{array}$} \\
\hline $\begin{array}{l}\text { South China Sea - northern } \\
\text { continental shelf } \\
\text { (Qui, 1988) }\end{array}$ & & & & & & & & & & & & \\
\hline
\end{tabular}

Fig. 10. Summary of the major assemblages resulting from previous community structure studies in Tropical Asia (Adapted from Silvestre et al., 2003). The different shading in each area depict the different fish assemblages determined from the analyses. Depth ranges with no shading are not covered by the survey or analysis (Bianchi, 1992, 1996; Bianchi et al., 1996; McManus, 1986, 1989, 1996; Srinath et al., 2003; Federizon, 1992; Chittima and Wannakiat, 1992; Khongchai et al., 2003; Qui, 1988).

Table 5

Spatial delineation of small and large-scale fisheries in Asia based on existing legal legislation

\begin{tabular}{|c|c|c|c|c|c|}
\hline \multirow[t]{2}{*}{ Countries } & \multicolumn{4}{|c|}{ Reference point: distance from shoreline } & \multirow[t]{2}{*}{ Source/reference } \\
\hline & Fishing Zone I & Fishing Zone II & Fishing Zone III & Fishing Zone IV & \\
\hline Brunei Darussalam & $\begin{array}{l}\text { Shore to } 3 \mathrm{~nm} \text { (small-scale } \\
\text { fisheries) }\end{array}$ & $\begin{array}{l}3-20 \mathrm{~nm} \text { (small-scale } \\
\text { fisheries and industrial } \\
\text { fisheries: trawlers } \\
<350 \mathrm{HP} \text {; purse } \\
\text { seiners }<20 \mathrm{~m} \mathrm{LOA} \text { ) }\end{array}$ & $\begin{array}{l}20-45 \mathrm{~nm} \text { (small-scale } \\
\text { fisheries and industrial } \\
\text { fisheries: trawlers with } \\
350-550 \mathrm{HP} \text {; purse seiners } \\
\text { with } 20-30 \mathrm{~m} \mathrm{LOA} \text { ) }\end{array}$ & $\begin{array}{l}45 \mathrm{~nm} \text { to EEZ limit } \\
\text { (small-scale fisheries } \\
\text { and industrial } \\
\text { fisheries: purse } \\
\text { seiners }>30 \mathrm{~m} \mathrm{LOA} \text { ) }\end{array}$ & $\begin{array}{l}\text { Silvestre and } \\
\text { Matdanan (1992), } \\
\text { SEAFDEC (1999) }\end{array}$ \\
\hline Indonesia & $\begin{array}{l}\text { Shore to } 3 \mathrm{~nm} \text { (small-scale } \\
\text { fisheries and fishing vessel } \\
<5 \mathrm{GT} / 10 \mathrm{HP}\end{array}$ & $\begin{array}{l}7 \mathrm{~nm} \text { (small-scale } \\
\text { fisheries and fishing } \\
\text { vessel }<25 \mathrm{GT} / 50 \mathrm{HP} \text { ) }\end{array}$ & $\begin{array}{l}12 \mathrm{~nm} \text { (industrial fisheries } \\
\text { and fishing vessel } \\
<100 \mathrm{GT} / 200 \mathrm{HP} \text { ) }\end{array}$ & $\begin{array}{l}>12 \mathrm{~nm} \text { (industrial } \\
\text { fisheries fishing vessel } \\
>100 \mathrm{GT} / 200 \mathrm{HP} \text { ) }\end{array}$ & Purwanto (2003) \\
\hline Malaysia & $\begin{array}{l}\text { Shore to } 5 \mathrm{~nm} \text { (traditional } \\
\text { fisheries, owner operated } \\
\text { vessels) }\end{array}$ & $\begin{array}{l}5-12 \mathrm{~nm} \text { (commercial } \\
\text { fisheries, for } \\
\text { owner-operated } \\
\text { trawlers and purse } \\
\text { seines <40 GT) }\end{array}$ & $\begin{array}{l}1230 \mathrm{~nm} \text { (commercial } \\
\text { fisheries, for trawlers and } \\
\text { purse seines }>40 \mathrm{GT} \text {, wholly } \\
\text { owned and operated by } \\
\text { Malaysian fishers) }\end{array}$ & $\begin{array}{l}30 \mathrm{~nm} \text { to EEZ } \\
\text { (commercial fisheries, } \\
\text { for deep sea fishing } \\
\text { vessels of }>70 \mathrm{GT} \text { ) }\end{array}$ & $\begin{array}{l}\text { Saharuddin (1995), } \\
\text { Abu Talib and Alias } \\
\text { (1997) }\end{array}$ \\
\hline Myanmar & $\begin{array}{l}5 \mathrm{~nm} \text { in the northern area; } \\
10 \mathrm{~nm} \text { in southern area } \\
\text { (coastal fisheries: boats of } \\
<30 \text { feet or using }<12 \mathrm{HP} \text { ) }\end{array}$ & $\begin{array}{l}\text { Outer limit of fishing } \\
\text { zone to EEZ limit } \\
\text { (industrial fisheries: } \\
\text { boats of }>30 \text { feet long } \\
\text { or using }>12 \text { HP } \\
\text { engines) }\end{array}$ & - & - & SEAFDEC (1999) \\
\hline
\end{tabular}


Table 5 (Continued)

\begin{tabular}{|c|c|c|c|c|c|}
\hline \multirow[t]{2}{*}{ Countries } & \multicolumn{4}{|c|}{ Reference point: distance from shoreline } & \multirow[t]{2}{*}{ Source/reference } \\
\hline & Fishing Zone I & Fishing Zone II & Fishing Zone III & Fishing Zone IV & \\
\hline Philippines & $\begin{array}{l}15 \mathrm{~km} \text { (municipal fisheries: } \\
\text { using fishing vessels }<3 \mathrm{GT} \\
\text { or fishing not requiring the } \\
\text { use of fishing vessels) }\end{array}$ & $\begin{array}{l}15 \mathrm{~km} \text { to EEZ limit } \\
\text { (commercial fisheries: } \\
\text { Small-scale - with } \\
\text { passive or active } \\
\text { fishing gear utilizing } \\
\text { fishing vessels } \\
>3.1 \mathrm{GT}\end{array}$ & - & - & $\begin{array}{l}\text { Barut et al. (2003), } \\
\text { Philippine Congress } \\
\text { (1998) }\end{array}$ \\
\hline Thailand & $\begin{array}{l}\text { Shore to } 12 \mathrm{~nm} \text { (small-scale } \\
\text { fisheries with boats }<5 \mathrm{GT} \text { ) }\end{array}$ & $\begin{array}{l}12 \mathrm{~nm} \text { to EEZ limit } \\
\text { (large-scale fisheries } \\
\text { with boats }>5 \mathrm{GT} \text { ) }\end{array}$ & - & - & SEAFDEC (1999) \\
\hline Bangladesh & $\begin{array}{l}\text { Shore to } 40 \mathrm{~m} \text { depth } \\
\text { (traditional/Artisanal } \\
\text { fisheries) }\end{array}$ & $\begin{array}{l}>40 \mathrm{~m} \text { to EEZ } \\
\text { (commercial fisheries) }\end{array}$ & - & - & Rahman et al. (2003) \\
\hline \multirow[t]{2}{*}{ India } & $\begin{array}{l}\text { Northern sector: shore to } \\
16 \mathrm{~m} \text { depth }\end{array}$ & $\begin{array}{l}\text { Northern sector: } \\
16-20 \mathrm{~m} \text { depth }\end{array}$ & $\begin{array}{l}\text { Northern sector: } 20-40 \mathrm{~m} \\
\text { depth }\end{array}$ & $\begin{array}{l}\text { Deep sea fishing, } \\
\text { vessels }>25 \text { GRT and } \\
\text { engine }>120 \mathrm{HP}\end{array}$ & $\begin{array}{l}\text { Vivekanandan et al. } \\
(2003)\end{array}$ \\
\hline & $\begin{array}{l}\text { Southern sector: shore to } \\
32 \mathrm{~m} \text { depth, Artisanal } \\
\text { craft/traditional gears }\end{array}$ & $\begin{array}{l}\text { Southern sector: } \\
32-40 \text { m depth, } \\
\text { motorized craft using } \\
\text { traditional gear }\end{array}$ & $\begin{array}{l}\text { Southern sector: } 40-70 \mathrm{~m} \\
\text { depth, small mechanized: } \\
\text { vessels < } 25 \text { GRT }\end{array}$ & & \\
\hline Cambodia & $\begin{array}{l}\text { Shore to } 20 \mathrm{~m} \text { depth (coastal } \\
\text { fisheries boat without engine } \\
\text { or with engine from } 5 \text { to } \\
50 \mathrm{HP} \text { ) }\end{array}$ & $\begin{array}{l}20 \mathrm{~m} \text { to EEZ limit } \\
\text { (commercial fisheries } \\
\text { with boat engine } \\
>50 \mathrm{HP} \text { ) }\end{array}$ & - & - & SEAFDEC (1999) \\
\hline Vietnam & $\begin{array}{l}\text { Shore to } 30 \mathrm{~m} \text { depth in } \\
\text { Northern and Southern areas, } \\
\text { to } 50 \mathrm{~m} \text { depth in Central area } \\
\text { (small-scale fisheries with } \\
\text { boats with no engine and with } \\
\text { engine }<40 \mathrm{HP} \text { ) }\end{array}$ & $\begin{array}{l}30-50 \mathrm{~m} \text { depth to the } \\
\text { EEZ limit (large-scale } \\
\text { fisheries and boats } \\
\text { with engine }>40 \mathrm{HP} \text { ) }\end{array}$ & - & - & SEAFDEC (1999) \\
\hline
\end{tabular}

Based from Silvestre et al., 2003.

data sets were analyzed separately by season (i.e., pre- and post-monsoon) to rectify this problem. The emergence of a single assemblage on the east coast of Peninsular Malaysia may be attributed to the analysis approach undertaken by Alias (2003). The Malaysia data was pooled across survey years and this may not have taken into account some seasonality or temporal trends. It would be valuable to use other analysis tools or software to validate the results more thoroughly. For example, canonical correspondence analysis (CCA), performs quite well with skewed species distributions, quantitative noise in species abundance data, samples taken from unusual sampling designs, highly inter-correlated environmental variables, and in situations where not all of the factors determining species composition are known (Palmer, 1993).

\section{Conclusions}

Assemblage analyses have the potential to provide valuable inputs into fisheries management, particularly in multispecies fisheries, such as the trawl fishery in South and Southeast Asia. They can assist in: (i) determining geographical or spatial boundaries of fish assemblages (Tyler et al., 1982; McManus, 1986, 1997); (ii) subdividing fisheries into components subjected to simultaneous conditions, e.g. effect of fishing pressure (Suvavepun, 1991), and changes in environmental conditions (Kihara and Itosu, 1989); (iii) design management interventions to partition different fisheries or gears based on spatial patterns of fish assemblages. This paper provides an example of a regional project, in which standardized analyses framework was used, enabling cross-country comparisons. This has clearly shown consistent trends in the coastal fish assemblages, with spatial structuring present in all areas and depth as a potential driving factor. Based on this, we have raised concern regarding the existing spatial fisheries management zones, most of which are based on distance from shore and have not taken into account the assemblage structure. In order to effectively manage fishing effort on assemblages, the spatial structuring needs to be taken into account in delineating these zones. The existing fishing zones in Vietnam for example, which are based on depth, coincided with assemblage delineation shown here (i.e., 30-50 m). In order to manage the overall impact from different fisheries, gears or sectors, the delineation of management zones to partition fishing effort, needs to take into account the spatial patterns of resources. Based on the regional trends seen here, the fishery resources are delineated by depth at 30-50 m and at about 90-100 m. Management should examine how depth could be used as basis for revising the existing fishing zones 
rather than just distances from the shore. In terms of practicality, distance from shore may be easier to enforce, but the distance could be equated with the relevant depths and assemblages.

Finally, there would be substantial benefit in further regional analyses of assemblage structure, using the available scientific trawl survey data and related information. These should focus on: (1) local and regional changes in assemblages through time to determine temporal stability and examine the impact of anthropogenic effects, particularly fishing (e.g. the work of Pauly, 1988; Suvavepun, 1991); (2) using the spatial assemblage patterns in the construction and articulation of spatially-explicit ecosystem models and tools to describe their functioning and likely responses to changes in fishing pressure; (3) provision of scientific insights to assist in the management of marine resources and biodiversity conservation including identifying conservation areas for species or stocks based on their spatial distribution and abundances, e.g. site selection of marine protected areas or fish sanctuaries.

\section{Acknowledgements}

We would like to thank Ms. Nurulhuda Ahmad Fatan who assisted in the preparation of the maps and figures. Dr. Jamie Oliver, Dr. Neil Andrew and Dr. Menchie Ablan provided critical comments on an early draft of the article, and the anonymous reviewers for their constructive comments on the article.

\section{References}

Abu Talib, A., Alias, M., 1997. Status of fisheries in Malaysia-An overview. In: Silvestre, G., Pauly, D. (Eds.), Status and management of tropical coastal fisheries in Asia. ICLARM Conf. Proc. 53, pp. $47-61$.

Alias, M., 2003. Preliminary analysis of demersal fish assemblages in Malaysian waters. In: Silvestre, G., Garces, L., Stobutzki, I., Ahmed, M., Valmonte-Santos, R.A., Luna, C.Z., Lachica-Aliño, L., Munro, P., Christensen, V., Pauly, D. (Eds.), Assessment, Management and Future Directions for Coastal Fisheries in Asian Countries. WorldFish Center Conference Proceedings 67, pp. 207-225.

Barut, N.C., Santos, M.D., Mijares, L.L., Subade, R., Armada, N.B., Garces, L.R., 2003. Philippine coastal fisheries situation. In: Silvestre, G., Garces, L., Stobutzki, I., Ahmed, M., Valmonte-Santos, R.A., Luna, C.Z., Lachica-Aliño, L., Munro, P., Christensen, V., Pauly, D. (Eds.), Assessment, Management and Future Directions for Coastal Fisheries in Asian Countries. World Fish Center Conference Proceedings 67, pp. 885-914.

Bianchi, G., 1992. Zonation of demersal fishes of the East Africa continental shelf. A study based on the surveys of the R/V Dr. Fridtjof Nansen. In: Bianchi, G. (Ed.), Demersal Assemblages of Tropical Continental, Shelves, A Study Base on the Data Collected Through the Surveys with the RV "Dr. Fridtjof Nansen". Ph.D. Dissertation, University of Bergen, pp. 191-217.

Bianchi, G., 1996. Demersal fish assemblages of trawlable grounds off northwest Sumatra. In: Pauly, D., Martosubroto, P. (Eds.), Baseline Studies of Biodiversity: The Fish Resources of Western Indonesia. ICLARM Studies and Reviews 23, pp. 123-134.
Bianchi, G., Badrudin, M., Budihardjo, S., 1996. Demersal assemblages of the Java Sea: a study based on the trawl surveys of the R/V Mutiara 4. In: Pauly, D., Martosubroto, P. (Eds.), Baseline Studies of Biodiversity: The Fish Resources of Western Indonesia. ICLARM Studies and Reviews 23, pp. 55-61.

Blaber, S.J.M., Brewer, D.T., Salini, J.P., Kerr, J., 1990. Biomasses, catch rates and abundances of demersal fishes, particularly predators of prawns in tropical bay in the Gulf of Carpentaria. Aust. Mar. Biol. 107, 397-408.

Botsford, L., Micheli, F., Hastings, A., 2003. Principles for the design of marine reserves. Ecol. Appl. 13 (Suppl. 1), S25-S31.

Campos, W., 2003. Analysis of demersal fish assemblages in selected Philippine fishing grounds. In: Silvestre, G., Garces, L., Stobutzki, I., Ahmed, M., Valmonte-Santos, R.A., Luna, C.Z., Lachica-Aliño, L., Munro, P., Christensen, V., Pauly, D. (Eds.), Assessment, Management and Future Directions for Coastal Fisheries in Asian Countries. WorldFish Center Conference Proceedings 67, pp. 227-248.

Chittima, A., Wannakiat, T., 1992. Distribution of economically important demersal fish by depth off Chanthaburi, East Thailand. Thailand Mar. Fish. Res. Bull. 3, 37-44.

Christensen, V., 1998. Fishery-induced changes in a marine ecosystem: insight from models of the Gulf of Thailand. J. Fish Biol. 53, 128-142.

FAO, 2003. The Ecosystem Approach to Fisheries. FAO Technical Guidelines for Responsible Fisheries, vol. 4, no. Suppl. 2. FAO Fisheries Department, Rome, 112 pp.

Fager, E.W., Longhurst, A.R., 1968. Recurrent group analysis of species assemblages of demersal fish in the Gulf of Guinea. J. Fish. Res. Bd Canada 25, 1405-1421.

Fauth, J.E., Bernardo, J., Camara, M., Resetarits, W.J., Van Buskirk, J., McCollum, S.A., 1996. Simplifying the jargon of community ecology: a conceptual approach. Am. Nat. 147, 282-286.

Federizon, R.R., 1992. Description of the subareas of Ragay Gulf, Philippines, and their fish assemblages by exploratory data analysis. Aust. J. mar. Freshwater Res. 43, 379-391.

Hill, M.O., 1979. TWINSPAN-a FORTRAN Program for Arranging Multivariate data in an Ordered Two-way Table by Classification of the Individuals and Attributes. Section of Ecology and Systematics, Cornell University, Ithaca, New York.

Khongchai, N., Vibunpant, S., Eiamsa-ard, M., Supongpan, M., 2003. Preliminary analysis of demersal fish assemblages in the coastal waters of the Gulf of Thailand. In: Silvestre, G., Garces, L., Stobutzki, I., Ahmed, M., Valmonte-Santos, R.A., Luna, C.Z., Lachica-Aliño, L., Munro, P., Christensen, V., Pauly, D. (Eds.), Assessment, Management and Future Directions for Coastal Fisheries in Asian Countries. WorldFish Center Conference Proceedings 67, pp. 249-262.

Kihara, K., Itosu, C., 1989. Distribution and diversity of recurrent groups of demersal fishes in the South China Sea off Viet Nam. Bull. Jpn. Soc. Sci. Fish. 55, 1007-1010.

Kongprom, A., Khemakorn, P., Eiamsa-ard, M., Supongpan, M., 2003. Status of demersal fishery resources in the Gulf of Thailand. In: Silvestre, G., Garces, L., Stobutzki, I., Ahmed, M., Valmonte-Santos, R.A., Luna, C.Z., Lachica-Aliño, L., Munro, P., Christensen, V., Pauly, D. (Eds.), Assessment, Management and Future Directions for Coastal Fisheries in Asian Countries. WorldFish Center Conference Proceedings 67, pp. 137-152.

Longhurst, A.R., Pauly, D., 1987. Ecology of Tropical Oceans. Academic Press, New York, 407 pp.

McManus, J.W., 1986. Depth zonation in a demersal fishery in Samar Sea, Philippines. In: Maclean, J.L., Dizon, L.B., Hosillos, L.V. (Eds.), The First Asian Fisheries Forum. Asian Fisheries Society, Manila, Philippines, pp. 483-486.

McManus, J.W., 1989. Depth zonation in the demersal fishes of Southeast Asia: the southwest shelf of Indonesia. In: Proceedings of the Sixth Symposium on Coastal and Ocean management/ASCE, 11-14 July 1989, Charleston, South Carolina, pp. 1011-1022.

McManus, J., 1996. Marine bottomfish communities from the Indian Ocean Coast of Bali to Mid-Sumatra. In: Pauly, D., Martosubroto, 
P. (Eds.), Baseline Studies of Biodiversity: The Fish Resources of Western Indonesia. ICLARM Studies and Reviews 23, pp. 91-101.

McManus, J., 1997. Ecological community structure analysis: applications in fisheries management. In: Silvestre, G., Pauly, D. (Eds.), Status and management of tropical coastal fisheries in Asia. ICLARM Conference Proceedings 53, pp. 133-142.

Mustafa, M.G., 2003. Preliminary analysis of the demersal fish assemblages in Bangladesh waters of the Bay of Bengal. In: Silvestre, G., Garces, L., Stobutzki, I., Ahmed, M., Valmonte-Santos, R.A., Luna, C.Z., Lachica-Aliño, L., Munro, P., Christensen, V., Pauly, D. (Eds.), Assessment, Management and Future Directions for Coastal Fisheries in Asian Countries. WorldFish Center Conference Proceedings 67, pp. $153-162$.

Nurhakim, S., 2003. Analysis of demersal assemblages off the North coast of central Java, Indonesia. In: Silvestre, G., Garces, L., Stobutzki, I., Ahmed, M., Valmonte-Santos, R.A., Luna, C.Z., Lachica-Aliño, L., Munro, P., Christensen, V., Pauly, D. (Eds.), Assessment, Management and Future Directions for Coastal Fisheries in Asian Countries. WorldFish Center Conference Proceedings 67, pp. 187-205.

Palmer, M.W., 1993. Putting things in even better order: the advantages of canonical correspondence analysis. Ecology 74, 2215-2230.

Pauly, D., 1988. Fisheries research and the demersal fisheries of Southeast Asia. In: Gulland, J.A. (Ed.), Fish Population Dynamics. John Wiley, London, pp. 329-348.

Philippine Congress, 1998. The Philippine Fisheries Code of 1998: Republic Act No. 8550. Metro Manila, Philippines.

Purwanto, 2003. Status and management of the Java Sea fisheries. In: Silvestre, G., Garces, L., Stobutzki, I., Ahmed, M., Valmonte-Santos, R.A., Luna, C.Z., Lachica-Aliño, L., Munro, P., Christensen, V., Pauly, D. (Eds.), Assessment, Management and Future Directions for Coastal Fisheries in Asian Countries. WorldFish Center Conference Proceedings 67 , pp. 793-832.

Qui, Y., 1988. A preliminary analysis of fish species groups on the northern continental shelf of South China Sea. J. Fish. China 14, 267-276.

Rahman, M.M., Chowdhury, Z.A., Sada, M.N.U., 2003. Coastal resources management, policy and planning in Bangladesh. In: Silvestre, G., Garces, L., Stobutzki, I., Ahmed, M., Valmonte-Santos, R.A., Luna, C.Z., Lachica-Aliño, L., Munro, P., Christensen, V., Pauly, D. (Eds.), Assessment, Management and Future Directions for Coastal Fisheries in Asian Countries. World Fish Center Conference Proceedings 67, pp. 689-756.

Roberts, C.M., Bohnsack, J.A., Gell, F., Hawkins, J.P., Goodridge, R., 2001. Effects of marine reserves on adjacent fisheries. Science 294, $1920-1923$.

Saharuddin, A.H., 1995. Development and management of Malaysian marine fisheries-technical conservation measures. Mar. Pol. 19, $115-126$.

Sale, P.F., Cowen, R.K., Danilowicz, B.S., Jones, G.P., Kritzer, J.P., Lindeman, K.C., Planes, S., Polunin, N.V.C., Russ, G.P., Sadovy, Y.J., Steneck, R.S., 2005. Critical science gaps impede use of no-take fishery reserves. Trends Ecol. Evol. 20, 74-80.

SAS Institute, 1994. SAS/STAT user's guide, version 6, vol. 12., 4th ed. Cary, NC, USA, 1686 pp.

SEAFDEC, 1999. Highlights of the SEAFDEC interdepartmental collaborative research program on fishery resources in the South China Sea, Area II: Waters of Sabah, Sarawak (Malaysia) and Brunei Darussalam. Special Paper No. SEC/SP/40. Southeast Asian Fisheries Development Center, Bangkok, Thailand.

Silvestre, G., Matdanan, M.J.H., 1992. Brunei Darussalam capture fisheries: a review of resources, exploitation and management. In: Sil- vestre, G., Matdanan, M.J.H., Sharifuddin, P.H.Y., De Silva, Chua, T.E. (Eds.), The coastal resources of Brunei Darussalam: status, utilization and management. ICLARM Conference Proceedings 34, pp. $1-38$.

Silvestre, G.T., Garces, L.R., Stobutzki, I., Ahmed, M., ValmonteSantos, R., Luna, C.Z., Zhou, W., 2003. South and South-east Asian Coastal Fisheries: their Status and Directions for Improved Management-Conference synopsis and recommendations. In: Silvestre, G., Garces, L., Stobutzki, I., Ahmed, M., Valmonte-Santos, R.A., Luna, C.Z., Lachica-Aliño, L., Munro, P., Christensen, V., Pauly, D. (Eds.), Assessment, Management and Future Directions for Coastal Fisheries in Asian Countries. World Fish Center Conference Proceedings 67 , pp. $1-40$.

Srinath, M., Pillai, V.N., Vivejanandan, E., Kurup, K.N., 2003. Demersal fish assemblages of the Southwest coast of India. In: Silvestre, G., Garces, L., Stobutzki, I., Ahmed, M., Valmonte-Santos, R.A., Luna, C.Z., Lachica-Aliño, L., Munro, P., Christensen, V., Pauly, D. (Eds.), Assessment, Management and Future Directions for Coastal Fisheries in Asian Countries. World Fish Center Conference Proceedings 67, pp. $163-185$.

Staunton-Smith, J., Blaber, S.J.M., Greenwood, J.G., 1999. Interspecific differences in the distribution of adult and juvenile ponyfish (Leiognathidae) in the Gulf of Carpentaria. Aust. Mar. Freshwater Res. 50, 643-653.

Stobutzki, I.C., Silvestre, G.T., Garces, L.R., 2006. Key issues in coastal fisheries in South and Southeast Asia, outcomes of a regional initiative. Fish. Res. 78, 109-118.

Suvavepun, S., 1991. Long term ecological changes in the Gulf of Thailand. Mar. Poll. Bull. 23, 213-217.

Taupek, M., Nasir, M., 2003. Monitoring, measurement and assessment of fishing capacity - the Malaysian experience. In: Pascoe, S., Greboval, D. (Eds.), Measuring Capacity in Fisheries. FAO Fisheries Technical Paper No. 445, pp.127-142.

Ter Braak, C.F.J., 1988. CANOCO-A FORTRAN Program for Canonical Community Ordination by Partial Detrended Canonical Correspondence Analysis, Principal Components Analysis and Redundancy Analysis (Version 2.1). Agricultural Mathematics Group, Wageningen, The Netherlands, 95 pp.

Tyler, A.V., Gabriel, W.L., Overholtz, W.J., 1982. Adaptive management based on structure of fish assemblages of northern continental shelves. In: Mercer, M.C. (Ed.), Multispecies Approaches to Fisheries Management Advise. Can. Spec. Publ. Fish. Aquat. Sci. 59, 149-156.

Vanderklift, M.A., Ward, T.J., Phillips, J.C., 1998. Use of assemblages derived from different taxonomic levels to selects areas for conserving marine biodiversity. Biol. Conserv. 86, 307-315.

van Groenewoud, H., 1992. The robustness of correspondence, detrended correspondence and TWINSPAN analysis. J. Veg. Sci. 3, 239-246.

Vivekanandan, E., Srinath, M., Pillai, V.N., Immanuel, S., Kurup, K.N., 2003. Marine fisheries along the southwest coast of India. In: Silvestre, G., Garces, L., Stobutzki, I., Ahmed, M., Valmonte-Santos, R.A., Luna, C.Z., Lachica-Aliño, L., Munro, P., Christensen, V., Pauly, D. (Eds.), Assessment, Management and Future Directions for Coastal Fisheries in Asian Countries. WorldFish Center Conference Proceedings 67 , pp. 757-792.

Watson, R.A., Dredge, M.L.C., Mayer, D.G., 1990. Spatial and seasonal variation in demersal trawl fauna associated with a prawn fishery on the Central Great Barrier Reef, Australia. Aust. J. Mar. Freshwater Res. 41, 65-77.

Zar, J.H., 1984. Biostatistical Analysis. Prentice-Hall, New Jersey, USA, $718 \mathrm{pp}$. 